\title{
An observation of gestational weight gain in obese pregnancies
}

\author{
J.C. Abayomi ${ }^{1}$, M.S. Charnley ${ }^{1}$, A. Weeks ${ }^{2}$ and J.P.H Wilding ${ }^{3}$ \\ ${ }^{1}$ Faculty of Education, Health \& Community, Liverpool John Moores University, Liverpool, United Kingdom L17 6BD, \\ ${ }^{2}$ Liverpool Women's Hospital, Crown Street, Liverpool L8 7SS and ${ }^{3}$ University Hospital Aintree, Longmoor Lane, \\ Liverpool L9 $7 A L$
}

Currently there are no UK guidelines regarding safe weight gain in pregnancy. Obesity (BMI $\geqslant 30 \mathrm{~kg} / \mathrm{m}^{2}$ ) and excessive weight gain in pregnancy are associated with serious health risks to both mother and baby including gestational diabetes, macrosomia, preeclampsia, caesarean section and post operative complications ${ }^{1}$. In the absence of UK guidance, USA recommendations are often referred to which suggest that women with a pre-pregnancy BMI $>29.9 \mathrm{~kg} / \mathrm{m}^{2}$ should limit gestational weight gain (GWG) to $5-9 \mathrm{~kg}^{2}$. The aim of this study was to explore patterns of GWG in obese pregnancies in comparison to USA IOM recommendations. Women with BMI $>29.9 \mathrm{~kg} / \mathrm{m}^{2}$ were recruited from antenatal clinic at booking-in appointments and agreed to being weighed at each trimester of pregnancy. Weight change was calculated and then compared with categorised pregnancy weight gain $(<0 \mathrm{~kg}, 0-5$ $\mathrm{kg}, 5-9 \mathrm{~kg}$ and $>9 \mathrm{~kg}$ ). Between June 2009 and June 2010, 824 women consented to participate and weight data were collected for 756 women (table 1).

Table 1: Gestational weight gain compared to USA IOM BMI categories

\begin{tabular}{|c|c|c|}
\hline $\begin{array}{l}\text { Initial BMI (number of women with } \\
1 \text { st \& 3rd trimester weights) }\end{array}$ & $\begin{array}{l}\text { Gestational weight gain } \\
\text { (GWG) }\end{array}$ & $\mathrm{N}$ ( $\%$ of $\mathrm{BMI}$ group) \\
\hline $30-34.9$ & $>9 \mathrm{~kg}$ & $102(45 \cdot 1)$ \\
\hline \multirow[t]{3}{*}{$(226)$} & $5 \cdot 1-9 \mathrm{~kg}$ & $51(22 \cdot 5)$ \\
\hline & $0-5 \mathrm{~kg}$ & $62(27.4)$ \\
\hline & Weight loss & $11(4 \cdot 9)$ \\
\hline $35-39 \cdot 9$ & $>9 \mathrm{~kg}$ & $53(40 \cdot 1)$ \\
\hline \multirow{3}{*}{$(132)$} & $5 \cdot 1-9 \mathrm{~kg}$ & $33(25.0)$ \\
\hline & $0-5 \mathrm{~kg}$ & $37(28 \cdot 0)$ \\
\hline & Weight loss & $9(6 \cdot 8)$ \\
\hline$\geqslant 40$ & $>9 \mathrm{~kg}$ & $18(26 \cdot 0)$ \\
\hline \multirow[t]{3}{*}{ (69) } & $5 \cdot 1-9 \mathrm{~kg}$ & $14(20 \cdot 3)$ \\
\hline & $0-5 \mathrm{~kg}$ & $21(30.4)$ \\
\hline & Weight loss & $16(23 \cdot 2)$ \\
\hline \multirow[t]{4}{*}{ All (427) } & $>9 \mathrm{~kg}$ & $173(40 \cdot 5)$ \\
\hline & $5 \cdot 1-9 \mathrm{~kg}$ & $98(22.9)$ \\
\hline & $0-5 \mathrm{~kg}$ & $120(28 \cdot 1)$ \\
\hline & Weight loss & $36(8.4)$ \\
\hline
\end{tabular}

Missing weight data made statistical analysis difficult but results suggest that increasing booking-in BMI was associated with deceased risk of excessive weight gain $(>9 \mathrm{~kg})$. In a model to assess predictors of GWG a higher booking BMI was negatively associated with GWG $(\beta-0 \cdot 25,95 \% \mathrm{CI}-0.32$ to $-0.19, \mathrm{p}<0.001)$. Due to finite resources, only women with a booking-in BMI $\geqslant 40 \mathrm{~kg} /$ $\mathrm{m}^{2}$ are currently offered specialist obesity care at the study hospital, despite $\mathrm{NICE}^{3}$ recommending specialist care for BMI $\geqslant 30 \mathrm{~kg} / \mathrm{m}^{2}$. These results suggest that pregnant women with BMI $30-39.9 \mathrm{~kg} / \mathrm{m}^{2}$ may be at greater risk of excessive GWG and yet are only offered routine antenatal care. A review of ante natal care provision for overweight pregnancies is urgently needed.

1. Galtier-Dereure F, Boegner C \& Bringer J. (2000) Obesity and pregnancy: complications and cost. American Journal of Clinical Nutrition 71(5), $1242-1248$.

2. Institute of Medicine (2009) Weight gain during pregnancy: Re-examining the Guidelines. Available at http://www.iom.edu/ /media/Files/Report\% 20Files/2009/Weight-Gain-During-Pregnancy-Reexamining-the-Guidelines/Report $\% 20$ Brief $\% 20-\% 20$ Weight $\% 20$ Gain $\% 20$ During $\% 20$ Pregnancy. pdf

3. NICE (2010) Weight management before, during and after pregnancy. Available at: http://guidance.nice.org.uk/PH27 